<総 説 $>$

\title{
自動車への適用を考慮した接着部の強度調査について Adhesive Joining Strength Examination in Car Structures
}

井口博 行* Hiroyuki IGUCHI

\section{1.はじめに}

環境問題対応との一つとして, 二酸化炭素排出量の低減 に向けた種々の検討が進められており，特に輸送車雨関係 に関してはその手法として車体の軽量化が進められている。 その軽量化対策手法として，自動車ボデー関係では鋼板の 高張力化やアルミ化等，複数の材料がさまざまな組み合わ せで使われるケースがある。この様な多種の材料を使う設 計要求に合わせて車体における接合技術への必要性も多様 化しており，特に異種材料の接合部に対しては構造用接着 による接合技術のニーズが高まっていると考えられる1。

一方, 自動車特有の複雑な負荷状況における強度評価は 必要であり，その車体における接合部は構造上，応力集中 しやすい部位であり重要である。また更に，この接合部分 を効率的に評価して，新接合方法を車体構造へ効率的に適 用出来ることは開発における上で有用之考えられる。そこ で，(社）自動車技術会・疲労信頼性部門委員会において, 自動車での新接合方法の有効活用を目的とした『自動車構 造に特化した疲労試験方法の考案，並びに特性評価活動』 を $\mathrm{W} / \mathrm{G}$ にて活動実施中 ${ }^{2}$ であり，この中から接着接合に ついての検討内容を以下に説明する。

\section{2. 車体構造部の負荷把握と検討状況}

まずはじめに，接着接合の強度耐久性の確保 ${ }^{3)}$ のため には，実際の車体構造で接合部にかかる負荷を把握するこ とが必要である。そこで，車体における接合部（図 1) へ の入力普びにモードを $\mathrm{W} / \mathrm{G}$ 参加各社にて調査し，その調 查結果より引張・せん断等の様々な負荷モードが存在する ことが明らかとなった（図 2)。

*トヨ夕自動車(㑣車雨技術開発部 曼知県豐田市卜ヨ夕町 1 释地 テ 471-8572

Vehicle Engineering Development Div.

Toyota Motor Corporation

1, Toyota-cho, Toyota, Aichi, 471-8572 Japan
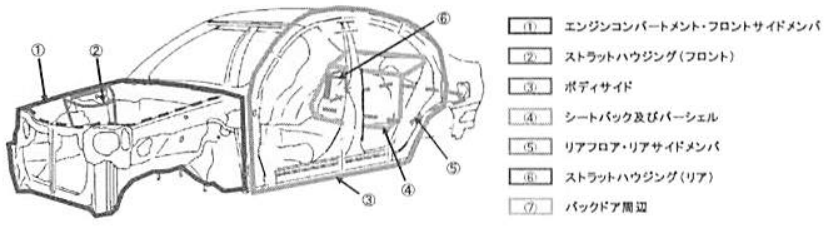

図 1 調查した車体接合部位

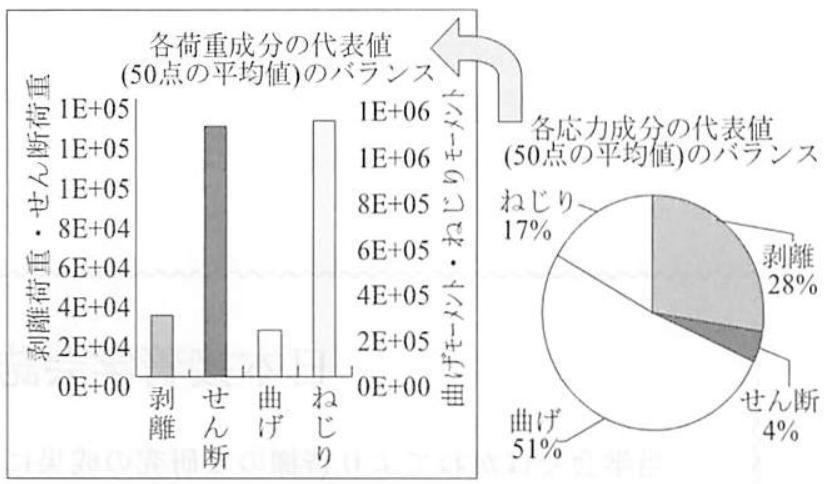

図 2 車両接合部の入力成分バランス

これより車体構造への適用の為にはこれらの各入力モー ドについて評価することが必要と考えられる。また，入力 モード以外では被着体となる各構造部ではその形状違い等 により，剛性が異なること，更には，構造によっては接合 部のそれぞれの寸法ばらつきによる接着部草さが異なる場 合む考えられる。以上を踏まえて，まずは評侕すべき武験 片形状について, 以下の様な事例を参考にして検討した。

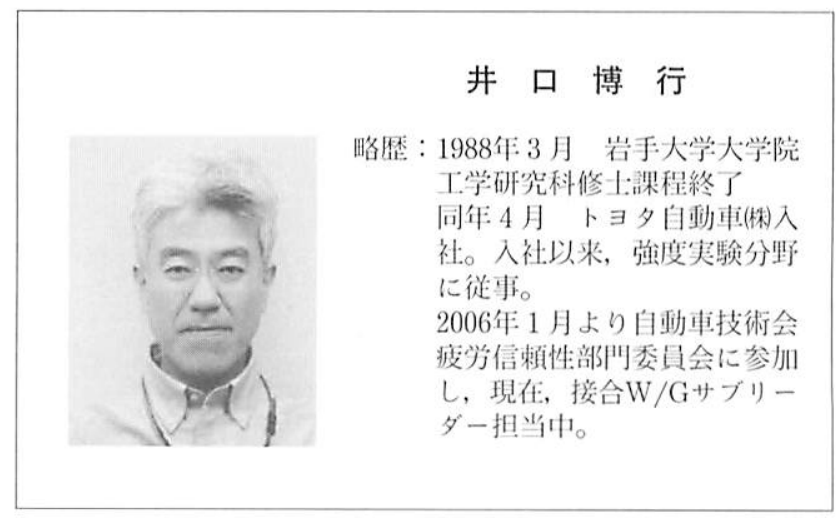


まず，本 W/G の母体である自動車技術会で過去に実施 されていた専門委員会, 特設委員会において, 『新時代を 担う構造接着技術』等にて自動車への適用を視野に入れた 多種の検討がなされている ${ }^{4)}$ 。本検討時の概要を大きくま とめると主には, 基本的なラップシア, ピールはく離と構 造体を考虑したハット型部材等により，スポット溶接等の 強度と比較した接着接合特性が報告されている。これらよ り，スポット溶接からの变更時における接合特性を検討す る上で有用なデータを提供している。また，本 W/G 活動 に限らず他の多くの接着接合に関する検討事例においても さまざまな形状の試験片について強度試験 ${ }^{5)}$ が実施され， 解析についても, 接着端における応力解析から, 単一応力 による報告事例としては，西川らは最大主応力を用いた評 価法 ${ }^{6)}$ を，今中らは最大引張応力を用いた評価法 ${ }^{7)}$ を, 森ら, 金子らは接着層の最大相当応力による評価法等 ${ }^{8,9)}$ にみられる事例がある。また，複数応力による方法として は，池上らは界面に垂直な応力とせん断応力の組合せによ る評価法 ${ }^{10)}$ 等にみられる様な事例がある。その他にあ結 城らはエネルギ開放率等 11$)$ のパラメータによる評価方法 がそれぞれ提案され手法としては多種に渡っている。

また，上記に示した『新時代を担う構造接着技術』後の 自技会関係の活動内容として，スポット溶接部評価方法を 検討する為に, DC 試験片による複合負荷評価を実施し $\sigma_{\mathrm{ns}}$ なるパラメータにより実構造物における疲労強度を統

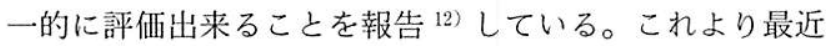
での検討傾向としては, より複雑な複合入力への対応を視 野に入れた実構造に近い状態での解析を可能にするための 強度調查並びに解析が実施されていることが分かる。以上 より接合部強度評価方法の傾向を示す内容としては,『実 構造を踏まえた複合入力に対応可能』, 『実構造と試験片レ ベルをスムースに繫ぐ事が容易な中間的な試験で，且つ従 来接合との比較が容易なこと』が上げられると考えられる。

\section{3. $\mathrm{W} / \mathrm{G}$ 活動概要}

上記の背景を踏まえた上で，本検討での目的は実構造で の実負荷状態を評価出来る試験方法並びに評価できるパラ メー夕を検討することとし，その為には既存接合やその他 の新接合との比較が実構造, 実負荷に近い形である評価方 法を探ることも重要である。その為，スポットから接着を 含めた種々の接合に対して, 接合全体の $W / G$ として, 共 通に使用可能な試験片となるBox 型試験片を提案し，複 合入力下での異なる接合方法の強度比較・解析の可能性を 検討している。

しかし，接着では被着体の剛性の影響が大きいことが予 想され，これらの影響を基本的な試験片でデー夕を把握す ることがまず必要と考えられ，Box 型試験片での被着体 剛性を制限した条件での評価，解析が必要と考えられた。
そこで, Box 試験片での検討に入る前に基礎的検討とし て, モードの違い, 被着体剛性の違い, 接着剂厚さの違い を含んだ数種類の試験片形状にて疲労強度を調査した。ま た, 解析方法としては車体レベルでの解析が効率的に出来 る範囲にて検討し, 各継手形式の統一的評価法を検討した ので,これらの内容について以下に述べる。

\section{4. 基本接着接合強度の調查方法}

接着接合強度の基本データを把握する為に実施した試験 方法を以下に示す。被着体材料として使用した鋼板は板厚 $1.2 \mathrm{~mm}$ で, 軽量化を考慮して, 材料強度では 270 材と 590 材の 2 種類にて調査した。接着剂は，1液加熱硬化型構造 用エポキシ接着剂を使用した。試験片は表 1 , 図 3 に示す ようにの 4 種類の試験片を用い, 接着剤厚さは $0.5 \mathrm{~mm}$,

$1.0 \mathrm{~mm}, 2.0 \mathrm{~mm}$ である。尚, ラップシア試験片以外では, 被着体の剛性の影響を制限する為に金属ブロックに被着体 を更に接着して剛性を高めて, 基本的特性が評価出来るこ とを狙っている。

\section{5. 接着接合強度調査結果}

試験結果であるが，はじめに，疲労試験後の破面を示す。 図 4 に 270 材ラップシア試験片の破断回数による違い，接

表 1 各負荷モードに対する継手形式

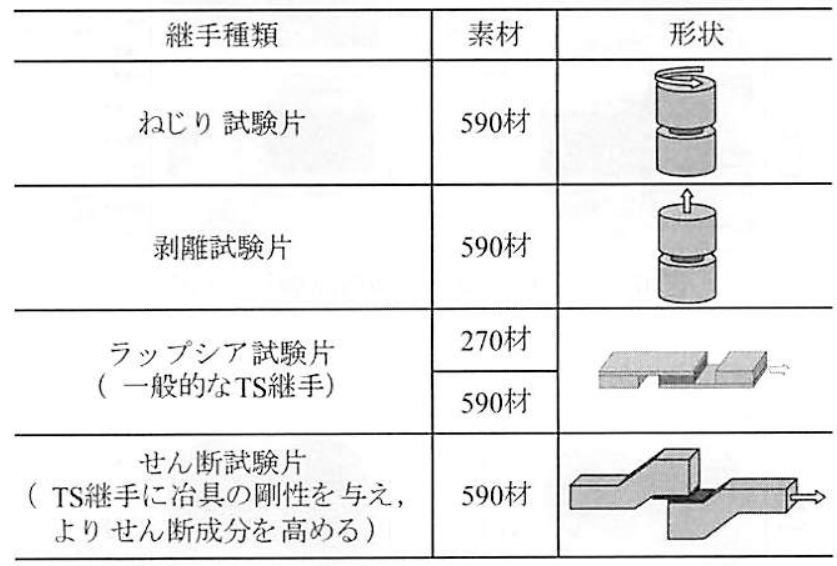
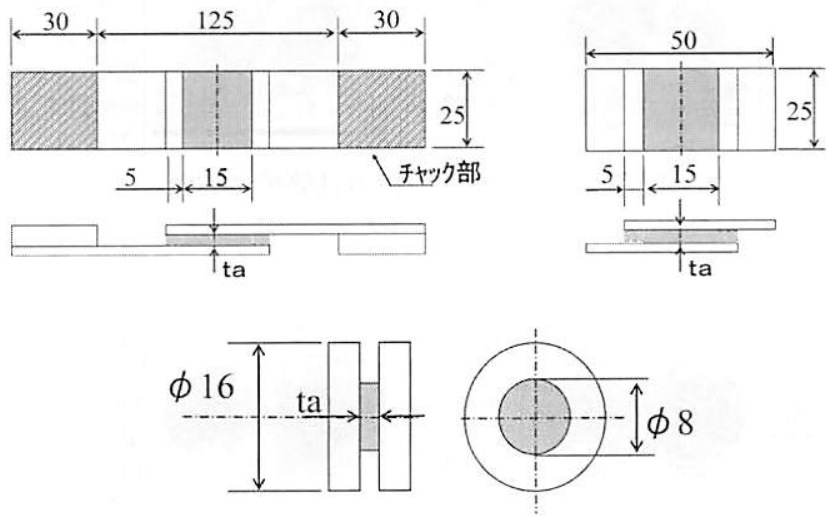

図 3 各試験片形状 


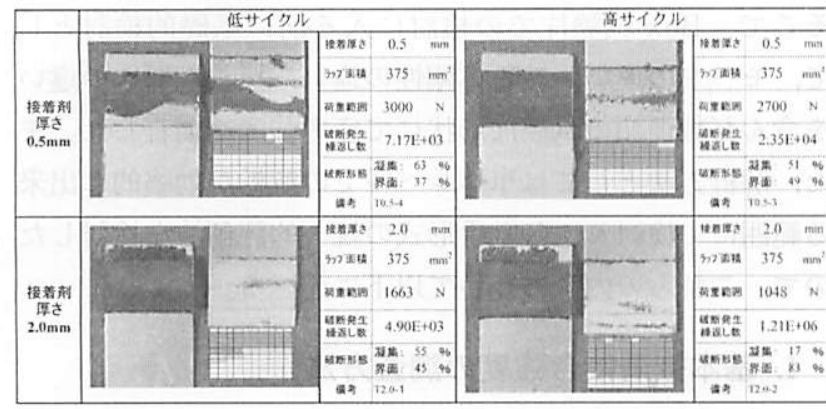

図 4270 材ラップシア試験片の疲労試験後の破面

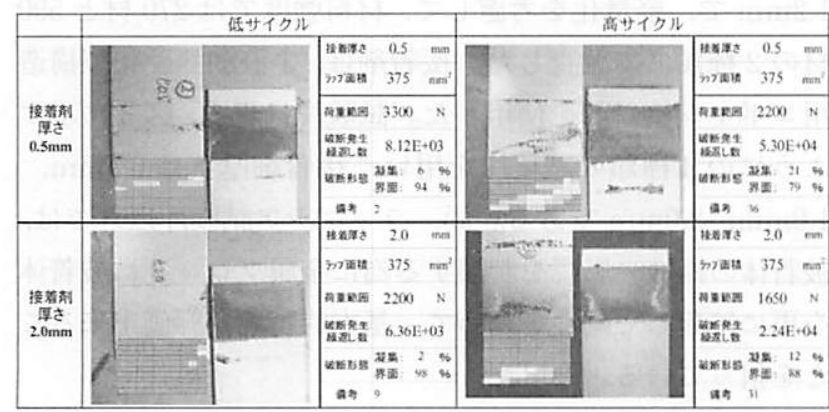

図 5590 材ラップシア試験片の疲労試験後の破面

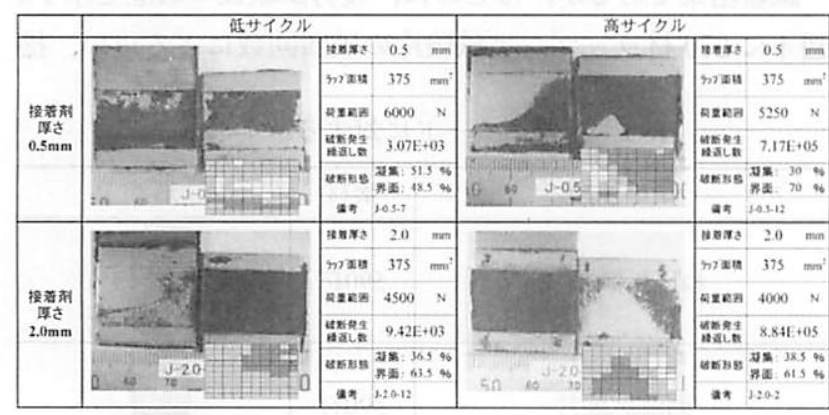

図 6 せん断試験片の疲労試験後の破面

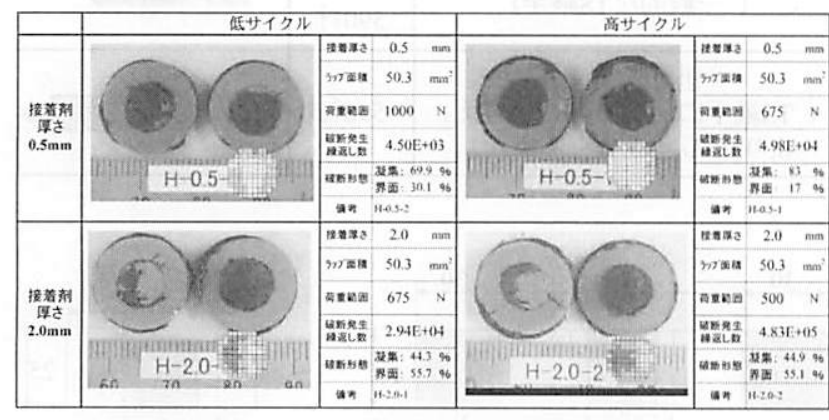

図 7 引張試験片の疲労試験後の破面

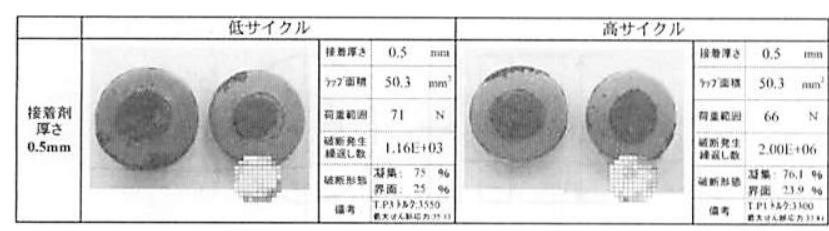

図 8 ねじり試験片の疲労試験後の破面
着剤厚さの違いのそれぞれについて示した。ラップシア試 験片では引張り側の接着端部がはく離モードとなり，き裂 の起点之考えられる。このき裂の起点では破面観察すると ほぼ界面破壊が観察され，その後にき裂が反対側の接着端 部まで伝播し破断するものと予想される。起点から破断ま でのき裂が伝播したと考えられる部分では凝集破壊である のに対して，高サイクル側や，接着剤厚さが厚くなった場 合では界面破壊の割合が増加していることが分かる。

図 5 に 590 材ラップシア武験片の疲労試験後の破面を示 す。き裂の起点は 270 材と同じく界面破壊であるが，伝播 もほぼ界面破壊であり，270 材に比べ，界面破壊の割合が 多い。

図 6 にせん断疲労試験後の破面を示す。き裂の起点と考 えられる接着端部では接着剤厚さやサイクルに関わらず多 くは界面破壊であるが, 接着剤が厚くなるにつれ, その界 面破壊の割合は大きくなる。なお，き裂の伝播部分はラッ プシア試験片に比べて凝集破壊が多い。

図 7 に引張疲労試験後の破面を示す。き裂の起点と推測 される接着阂端部では, サイクルに関わらず凝集破壊が生 じており，また，き裂の伝播も凝集破壊である。しかし， 接着剤厚さが厚い場合では, き裂の伝播において界面破壊 の割合が増加する。

最後に, 図 8 に水じり疲労試験後の破面を示す。き裂の 起点, き裂の伝播部共にほぼ凝集破壊である。

続いて, 試験結果の整理方法であるが, 本検討での疲労 試験結果の整理方法については, 検討初期にき裂発生繰返 し数を調べる為に, 試験片に張付けたひずみゲージのひず み変化を調べた。この時に同時に試験機变位との相関も調 査し, 試験機变位の变化によりき裂発生繰返し数が判ると 判断された為, 主に試験機変位によりき裂発生繰返し数と 破断繰返し数の関係を調べた。これより全寿命に対して, き裂発生寿命の割合が支配的と判断された為，变位による 破断繰返し数でき裂発生繰返し数の代用として結果を整理 している。

試験結果であるが, 各継手の疲労強度を比較すると, 本 試験片形状においては, ねじり試験片>引張試験片, せん 断武験片 $>590$ 材ラップシア試験片 $>270$ 材ラップシア試 験片となる。また全体の傾向としては, 接着風が厚くなる につれて接合部の疲労強度が低下寸る結果となった（図 9)。 さらに，スポット溶接武験片との比較をした結果を図 10 に示す。接着はスポット溶接に対し, せ九断・引張ともに 線図の傾きが大きく異なり，接着接合でも接合面の剛性を 上げることにより, 高サイクルにおいてスポット接合とほ ぼ同等の強度を得られると考えられる。

なお，上記の比較検討は, 270 材相当の同じ鋼板厚さに おけるスポット溶接 1 点あたりの瘦労データ ${ }^{13)}$ （引張り 


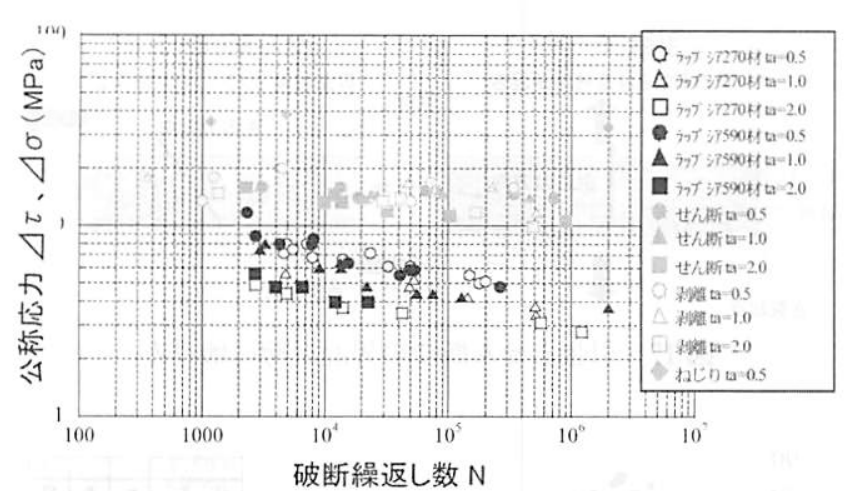

図 9 各継手形式の疲労試験結果

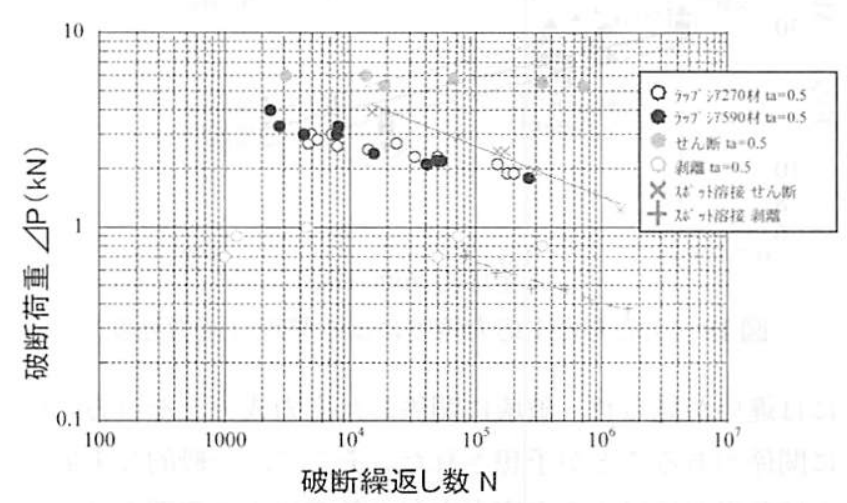

図 10 接着とスポット溶接試験片の疲労特性比較

せん断継手, 十字形引張り継手) と, 今回検討した接着面 積 $(25 \mathrm{~mm} \times 15 \mathrm{~mm})$ のラップシア試験片とせん断試験片, 接着面積 ( $(\Phi 8 \mathrm{~mm})$ の引張試験片とを比較した場合の結 果である。

\section{6. 接着接合部の応力解析}

続いて先の試験結果を統一的に評価する方法を検討する 為に, FEM 解析による検討を試みた。各 4 種類の継ぎ手 モデルを用意し，引張から稀じりまでの各試験片での応力 解析を実施した。解析したモデルの要素は 1 次のソリッド 要素を用い,メッシュサイズは車両での適用性む考慮して $1 \mathrm{~mm}$ 程度を基本とした。尚, 解析には汎用解析ソフトの NASTRAN を用い，一部，母材の変形が大きい条件につ いて ABAQUSによる解析を試みた。鋼板と接着剤の材 料特性は，表 2 の值を用いた。

解析結果であるが，まず，はじめに，各負荷モードにお ける応力集中の状態を, 引張, 世ん断の応力成分に分けて 調査した（図 12 15）。政じり試験片においては，応力集 中は見られず，公称応力とほぼ等しい值であることがわか る。また，接着剤厚さの影響む見られない（図 12）。引張 試験片では, 引張応力成分はほぼ均一で, せん断成分の応 力集中が大きく，接着剤の厚い方がその傾向が大きい（図 13)。せ九断試験片では, せん断応力成分に比へ, 引張成 分の応力集中が大きく, 接着剤の厚い方がその傾向が大き い（図 14）。ラップシア試験片では, 引張とせん断の両方
表 2 鋼板と接着剂の材料特性

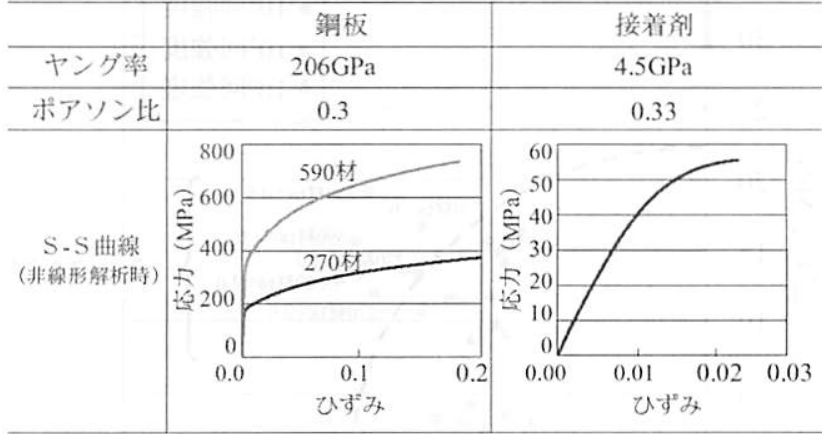
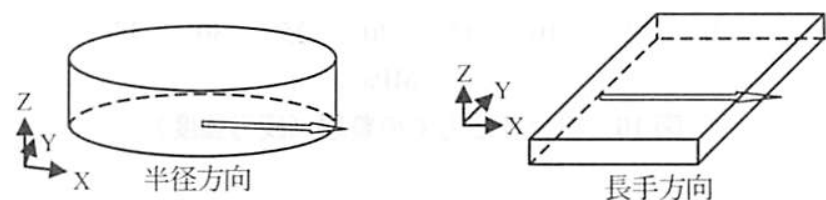

図 11 接着剤の応力抽出部位

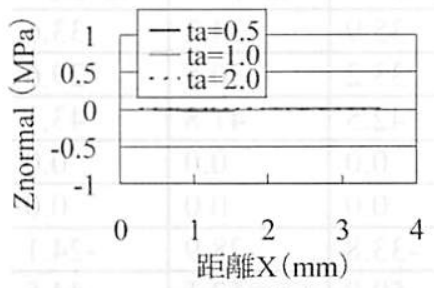

(a)引張応力 (b) せん断応力

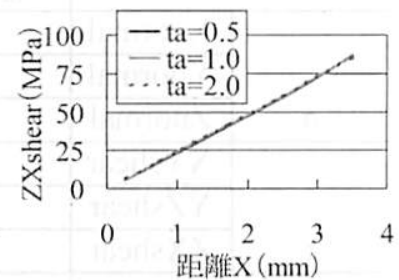

図 12 叔じり試験片の半径方向応力分布（負荷 $9.8 \mathrm{Nm}$ )

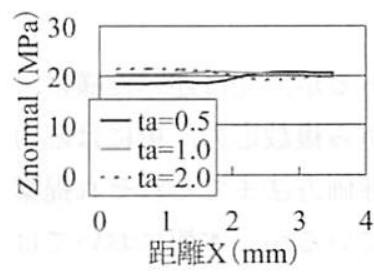

(a)引張応力

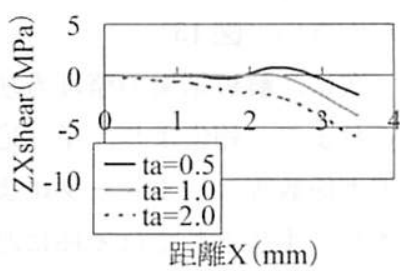

(b) せ九断応力
図 13 引張試験片の半径方向応力分布（負荷 $1 \mathrm{kN}$ )

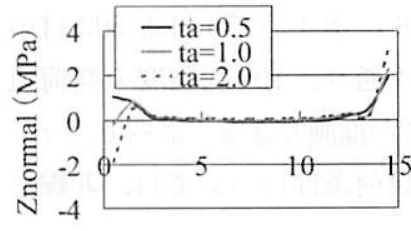

距䧺X $(\mathrm{mm})$

(a)引張応力

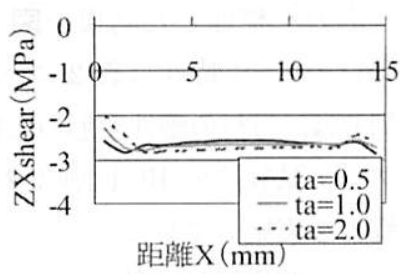

(b)せん断応力
図 14 せ九断試験片の長手方向応力分布（負荷 $1 \mathrm{kN}$ )

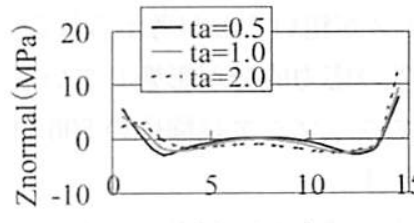

距離X $(\mathrm{mm})$

(a)引張応力

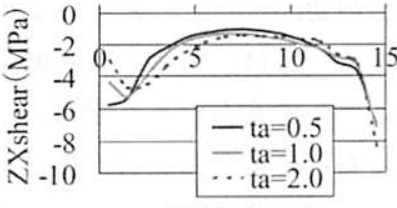

距離X $(\mathrm{mm})$

(b)せ九断応力
図 15 ラップシア試験片の長手方向応力分布（負荷 $1 \mathrm{kN}$ 


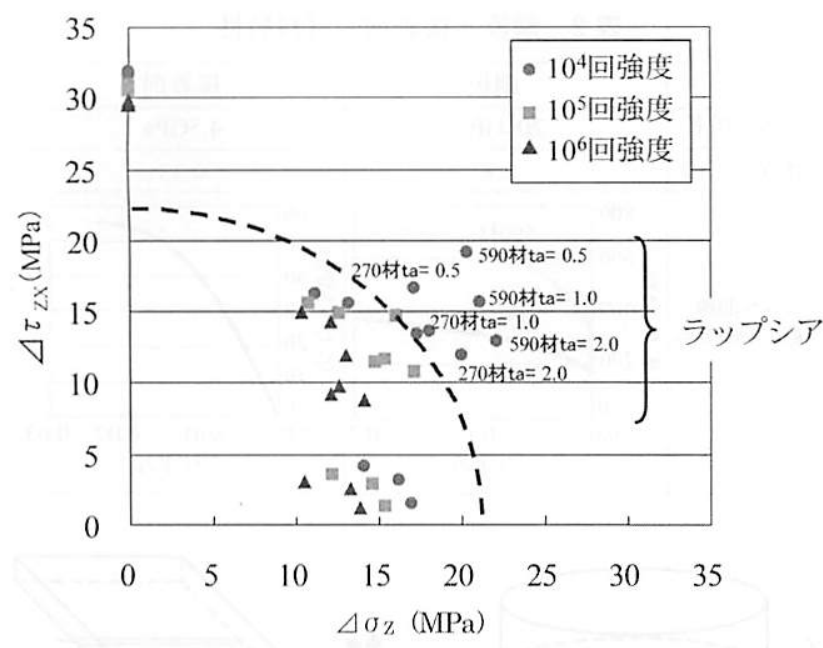

図 16 組合せ応力での整理（疲労強度）

表 3590 材ラップシア試験片の各応力成分（MPa）

\begin{tabular}{r|r|r|r|r}
\hline \multicolumn{2}{c|}{} & \multicolumn{1}{c|}{ ta=0.5 } & ta=1.0 & ta=2.0 \\
\hline \multirow{4}{*}{$\sigma$} & Xnormal & 35.9 & 34.2 & 33.6 \\
\cline { 2 - 5 } & Ynormal & 33.2 & 30.5 & 29.6 \\
\cline { 2 - 5 } & Znormal & 42.5 & 41.8 & 43.1 \\
\hline \multirow{4}{*}{$\tau$} & XYshear & 0.0 & 0.0 & 0.0 \\
\cline { 2 - 5 } & YZshear & 0.0 & 0.0 & 0.0 \\
\cline { 2 - 5 } & ZXshear & -33.8 & -28.9 & -24.1 \\
\hline \multicolumn{2}{|c}{ Mises } & 59.8 & 52.1 & 44.6 \\
\hline
\end{tabular}

の応力成分で応力集中があり, 接着剤が厚い方がその傾向 が大きい（図 15）

次に，解析結果の整理方法であるが，先に述べた様に， これまでの報告より, 単一応力から複数応力, 更には応力 拡大係数等のパラメータによる評価方法までそれぞれ提案 され，手法としては多種に渡っているが，本報においては 上記の各応力分布から 2 成分による試行からスタートして, 最終的には一般的な主応力による整理を試みた。その引張 応力 $\sigma_{Z}$, せん断応力 $\tau_{Z X}$ の 2 成分で, 各負荷モードの組合 せ応力を整理した結果を図 16 に示す。 270 材と 590 材の 母材の $\mathrm{S}-\mathrm{S}$ 特性は表 2 に示す通り, $10^{4}$ 回強度の高荷重 側では，母材の塑性变形の影響が推測できる。よって，ラッ プシア試験片の $10^{4}$ 回強度の負荷条件については, 非線形 解析を実施している。

この結果では，特にラップシア試験片において，他の負 荷モードとは異なる傾向を示した。非線形解析によりこの デー夕は改善されているが，バラッキが大きい状態である。 その要因として，メッシュサイズが粗いことが考えられる。 むう一つは, 引張とせん断以外の応力成分が影響している ことが考えられる。参考としてラップシア試験片の 590 材 における各応力成分を表 3 に示す。

上記を踏まえ，他の整理方法を試みたのが以下の内容で ある。今回，破面観察の結果（図 17）より，引張とせん 断では, 界面近傍の接着剂の壊れ方には微小な破面の角度

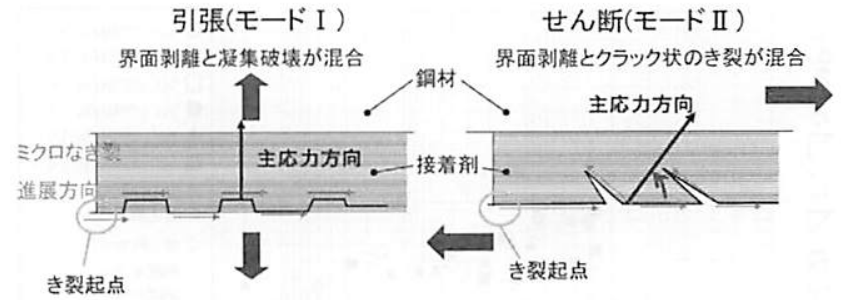

図 17 引張とせん断での界面近傍の壊れ方

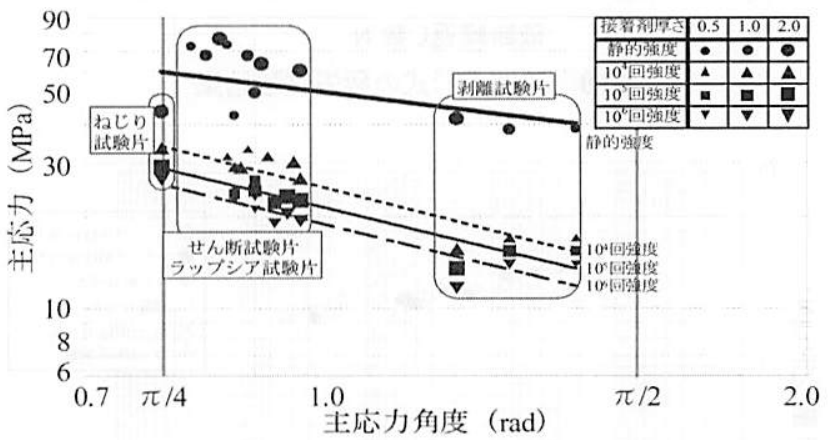

図 18 主応力と主応力角度による整理（疲労強度）

には違いが見られ，破壊に関係した応力成分とその方向性 に関係があることが予想された。そこで，一般的な主応力 と接着界面に対する主応力方向の角度による整理を試みた (図 18)。

図より疲労強度については統一的に整理出来る可能性が ある。この主応力の方向を用いた根拠については, 詳細検 討は出来ていないが, 一要因として, 解析モデルサイズが 大きい影響を修正している可能性む考えられ，今後の更な る検討が必要と考える。

\section{7. 本 $\mathrm{W} / \mathrm{G}$ 活動進渉状況まとめ}

ラップシア・せん断・引張・ねじり試験片により, 車体 に加わる各負荷モードを考虑した接着接合部の強度特性に ついて検討を行い，接着接合部を車体レベルでも比較的解 析が容易な FEM モデル解析により, 負荷モードと接着剤 厚さの影響を検討し，以下の結果を得た。

本試験片においても負荷モードの違い, 被着体剛性の影 響, および，接着剤厚さによる影響を受けて強度は变化す る。また, FEM 解析結果と破面観察結果より, 主応力の 方向による破壊形態の違いが推測され, 疲労強度について は, 主応力と主応力角度により各負荷モードと接着剤厚さ の影響を統一的に説明できる可能性がある。

\section{8.おわりに}

本活動は（社）自動車技術会・疲労信頼性部門委員会に おいて 2005 年から下記の参加各社の共同研究として活動 開始し, 現在も継続推進中の内容である。今後の予定では, 同 W/Gにて検討中の他接合（リベット・レーザ）と共通 の Box 型試験片への検討へと進む予定で，最終的にはこ 
れらの比較検討が容易に出来ることを目指している。同様 の検討が進み, 今後, 設計者が検討する際により効率的で 信頼性のある強度検討手法が普及し, 車体構造への新接合 方法適用により車体の軽量化が進み, 環境問題対応一の貢 献が出来る事を期待する。

\section{本 $\mathrm{W} / \mathrm{G}$ 参加メンパー（接着以外の点接合, 線接合, 接} 合の一部を含む：敬称略）

花井洋志, 石橋太郎（関東自動車工業株式会社）, 梅村 敏文 (トヨ夕車体株式会社), 伏谷裕士（富士重工業株式 会社), 杉浦裕 (サンスター技研株式会社), 中丸敏明, 湯 浅卓也（日産自動車株式会社）, 覚前正博, 山崎史博（卜 ヨ夕自動車株式会社), 佐藤千明 (東京工業大学)

\section{参考 文 献}

1）磨川元康, 車体接合/接着技術の現状と課題, 日本接着学会 年次大会, 46, 208 (2008).
2）中丸敏明, 接合構造評偄ワーキング活動概要, JSAE シン ポジゥム No. 01-08, 21 (2008).

3）富岡昇, 鋼板接着継手の疲労強度とその評侕, 新時代を担 う構造接着技術, No. 12，20（1990）.

4) 北川英夫, 結城良治, 新時代を担う構造接着技術, JSAE シンポジゥムNo. 12 (1990).

5）木原幸一郎, 短形接着面を有する十字形接着継手による接 着剤 ， 日本接着学会誌，38, 321 (2002).

6）西川哲也，厚賀康介，日本接着学会誌，22，244（1986).

7) 今中誠, 他 4 名, 重衫合せ接着継手の疲労強度推定, 材料, 35, 623 (1986).

8）森孝男, 他 3 名, 金属-FRP 接着継手の低温強度, 日本機 械論文集 A，56，437（1990）.

9）金子堅司, 接着強度とそのクライテリオン, 第 44 回日本接 着学会年次大会 (2005).

10）池上皓三, 接着継手の応力解析之強度設計, 日本機械論文 集 A，50，1557（1894）.

11）結城，日本機械論文集 A， 55，1984 (1989).

12) Yuji NAKAHARA, Method of Fatigue Life Estimation for Spot-, SAEPaper2000-01-0779p. 1-13 (2000).

13） スポット溶接継手疲労強度デー夕集, 自動車技術会, 疲労 信頼性部門委員会, 薄板接合構造信頼性分科会 (1987). 